\title{
Meetings
}

\section{REPORTS ON RECENT MEETINGS}

Colloquium on Pleistocene Problems in the Atlantic Provinces, Canadian Geographers Association Annual Meeting, St. John's, Newfoundland, August 22, 1969.

The following papers were given at this meeting:

Retreat of the Last Ice Sheet from the Atlantic Provinces Region - V. K. Prest, Geological Survey of Canada, Ottawa, Ontario.

Post-Glacial Uplift a round the Bay of Fundy - John Welsted, Brandon University, Manitoba. Late Pleistocene Glacial Events in Southwestern Newfoundland - Ian Brookes, York University, Toronto, Ontario.

Estimate of Maximum Post-Glacial Emergence in Port au Port Bay, Newfoundland - J. M. Shearer, Dalhousie University, Halifax, Nova Scotia.

Recent Submergence, Maritime Provinces - D. R. Grant, Geological Survey of Canada, Ottawa, Ontario.

Land and Sea-Level Fluctuations in Northumberland Strait - K. Kranck, Bedford Institute, Dartmouth, Nova Scotia.

On the Origin of the Laurentian Channel - Lewis H. King and Brian MacLean, Bedford Institute, Dartmouth, Nova Scotia.

Geography of the Atlantic Provinces and New England in Palaeo-Indian Time - Douglas Byers, and $\mathrm{H}$. W. Borns, Jr., Andover, Massachusetts.

Man in the Maritimes - Cultural Adaptations to Maritime Environment - Jim Tuck, Memorial University of Newfoundland, St. John's.

Prehistory in New Brunswick: a Progress Report - David Sanger, National Museum of Man, Ottawa.

New Global Tectonics Workship, Atlantic Oceanographic Laboratory, Bedford Institute, Dartmouth, Nova Scotia, August 27 and $28,1969$.

This workshop was convened at the Bedford Institute and was attended by scientists from various laboratories in the area. An outline of the program is as follows:

B. D. Loncarevic, Atlantic Oceanographic Laboratory - Introduction to Global Tectonics. R. L. Parker, Scripp Institute of Oceanography - Global Tectonics in the North Pacific.

P. A. Mohr, Seismological Observatory, Addis Ababa and Smithsonian Institution, Cambridge, Mass. - East African Rift System.

D. A. Christofell, Victoria University, New Zealand - Global Tectonics in the South Pacific.

B. D. Loncarevic, D. I. Ross, J. M. Woodside, and D. L. Barrett, Atlantic Oceanographic Laboratory, and C. E. Keen and M. J. Keen, Dalhousie University, Halifax - Global Tectonics in the North Atlantic including magnetics, gravity, seismics and geology. Workshop - Special discussions dealt with the following: Mid-Ocean Ridge studies, heat flow, seismicity, theoretical studies, and Labrador Sea studies.

On 27 and 28 August an informal workshop on the "New Global Tectonics" was held at the Bedford Institute, co-sponsored by its Marine Geophysics group and the Geology Department at Dalhousie. The "newness" of the new global tectonics was well illustrated by B. D. Loncarevic who opened the workshop. He pointed out that two thirds of the papers referred to by Isacks, Oliver, and Sykes when they set out the basic principles of this new concept in the 15 September. 1968 is sue of Journal of Geophysical Research, were written within the past five years. In other words, to paraphrase Dr. Loncarevic, any earth scientist who graduated more than five years ago and has not kept up to date with the increasing volume of literature in his field is sadly out of touch. Dr. Loncarevic went on to outline the accumulation of various important bits of information over the past few years which are suddenly fitting together as major elements in the framework of this exciting new geologic theory (for by now it has passed beyond the class of "hypothesis"). The new global tectonics is founded on the hypothesis of continental drift, seafloor spreading, transform faults, and underthrusting of the lithosphere (the upper $100 \mathrm{kilometers}$ of the earth's crust and mantle) at island arcs. It deals with the motions of large rigid mobile plates of the lithosphere and their interactions with each other. The surface of the earth is divided into six major plates with a growing number of smaller plates now being defined. Interactions between plates produce mid-oceanic ridges (or rises), oceanic trenches, and transform faults. 
R. L. Parker, who has during the past few years been present "where the action is" in England and the U.S. when some of the more important hypotheses pertinent to the new global tectonics were being formed, presented some of his thoughts on the subject and some of the most recent ideas being articulated by the main proponents of the theory. Dr. Parker is visiting the Bedford Institute from the Institute of Geophysics and Planetary Physics at Scripps Institution of Oceanography, for several weeks to continue work on our Mid-Atlantic Ridge data which he and Dr. Loncarevic began early this spring at Scripps. After first stating "the dogma" as he sees it, he went on to investigate certain implications of "the dogma"; in particular, the concept of "triple junctions". A triple junction is the intersection of transform faults, centres of sea-floor spreading (rises or ridges), and centres of destruction of sea-floor (island arcs or trenches) in any combination (e. g. three transform faults, or two transform faults and one ridge, etc.).

P. A. Mohr (Smithsonian Institution, Cambridge, Mass., and the Seis mological Observatory, Addis Ababa) and D. A. Christoffel (visiting Lamont-Doherty Geological Observatory on a leave of absence from Victoria University, New Zealand) both spoke on the fit of data from their own specific areas of interest to new global tectonics. Dr. Mohr's primary area of interest is the Ethiopian rift system. Dr. Christoffel reviewed the geophysics of the south Pacific near New Zealand, indicating his present interpretation of the geological evolution of the area. He supported his ideas concerning past motions of Australia and New Zealand with botanical data (as indicators of palaeoclimates), as well as geophysical data. In both the south Pacific and east Africa, triple junctions are present and both speakers showed how the theoretical considerations described by Dr. Parker hold up in the real world.

A review of the results which have come from our work on the Mid-Atlantic Ridge was presented by M. J. Keen, who chaired the afternoon session on the 27 th, D. I. Ross, and C. E. Keen. The purpose of this was to show how our results fitted in with the new global tectonics as discussed earlier and to bring our guests, who included a body of interested earth scientists from Nova Scotia as well as the principal speakers mentioned, up to date on our work. A discussion of these results followed on the morning of the 28th with emphasis placed on methods of analysis which might most effectively extract the most information from our data. P. J. Bhattacharya of Dalhousie discussed some of the techniques he has been using, mainly spectral analyses, on analyzing Mid-Atlantic Ridge data as part of a graduate project.

Also on the agenda for the 28 th was a talk by K. G. Shih on work he has been doing since joining the marine geophysics group earlier this year. He has been investigating the possible sources of oceanic high heat flow and the distribution of earthquakes.

The main benefits derived from the workshop were threefold. The basic tenets of the new global tectonics and the present implications of the concept were consolidated and fresh insight provided by the guests. We were given the opportunity of discussing this important new theory with the guests and applying different points of view of our own specific investigations on the Mid-Atlantic Ridge. The workshop also permitted other members of the Institute, plus interested people from the local area to discover the directions being taken in earth science today.

J. Woodside, Bedford Institute

FORTHCOMING MEETINGS

Symposium on the Geology of the East Atlantic Continental Margin, Cambridge, U. K. , March 23-26, 1970 .

This symposium is under the auspices of the Scientific Committee on Oceanic Research. It will include displays of maps, diagrams and other material near the lecture hall. Shorter regional contributions as well as several oral contributions will be given. Publication will be as a special report of the Institute of Geological Sciences UK, and may be bought from Her Majesty's Stationery Office, $49 \mathrm{High}$ Holborn, London SC 1 . The technical program is as follows:

K. O. Emery: x Structures of the Continental Margins of the World.

A. Guilcher: $x$ Quaternary Events on the Continental Margins of the World. 
E. M. Emilianov: xx Barents Sea.

H. Holtedahl: $x x$ Norwegian Sea and Baltic.

N. B. Price and P. L. Wright: Distribution of Minor Elements in Barents Sea.

G. L. Johnson, P. R. Vogt: Evolution of the Norwegian Basin.

H. Closs, Fromm, Hanel, Hinz, Plaumann: Some preliminary Geophysical Results 1 rom the Norwegian Sea.

J. D. Phillips: $x$ Sea floor spreading and the Tectonics of the Atlantic Basin.

B. J. Collette: $x x$ North Sea (Structure).

H. J. Veenstra: xx North Sea (Sediments).

M. H. P. Bott: xx Continental Margin adjacent to the British Isles (Deep structure).

R. A. Eden, J. B. Wright, W. Bullerwell: xx (ditto, Sediment structures).

R. H. Belderson, N. H. Kenyon, A. H. Stride: xx (ditto, Superficial sediments).

D. Hamilton: Submarine Geology of the western Approaches of the English Channel.

H. Lacombe: x Physical Oceanography of an Eastern Ocean Boundary.

J. Debyser: $x x$ Channel to Finisterre (Structure).

G. Boillot, M. Lamboy, Ph. Bouysse: $x x$ Channel to Finisterre (Sediments).

J. H. Monteiro: xx Finisterre to Casablanca.

E. Oele: Late Quaternary Geology of the North Sea S. E. of the Dogger Bank.

R. Keary: The biogenic Carbonate Fraction of Beach and shallow Shelf Sediments of the Irish Coast.

S. A. D. Bamford and D. J. Blundell: South West Britain Continental Margin Experiment.

R. J. Bailey, R. H. Clarke and D. Taylor-Smith: The Continental Margin West of Ireland.

R. Scrutton, D. G. Roberts, D. H. Matthews, A. S. Laughton: Structure of the Rockall Plateau and Trough, North East Atlantic.

F. Pasternak: $x$ Marine Biology of the East Atlantic Continental Region.

J. S. Tooms: $x x$ Rabat to Dakar.

R. Byramjee: xx Dakar to C. Palmas.

J. R. Delteil, M. Valery: xx C. Palmas to Lagos (Structure).

L. Martin: xx C. Palmas to Lagos (Morphology and Sediments).

J. Hospers: xx Niger Delta Area.

R. L. McMaster, T. P. Lachance, A. Ashraf and J. de Boer: Geomorphology, Structure and Sediments of the Continental Shelf off Portuguese Guinea, Guinea and Sierra Leone.

R. Gageonnet: $x x$ Niger to Congo.

G. P. Brognon: xx Angola.

E. S. W. Simpson: $x x$ Southwest - and South Africa.

P. L. Bezrukow: xx Soviet Contributions to the Geology of the African Continental Margin.

H. A. Roeser, S. Plaumann, K. Hinz: Continental Margin Structure in the Canaries.

E. D. Schneider: Deep Ocean Diapiric Structures.

P. A. Rona: Reflection and Magnetic Profiles between Canary and Cape Verde Islands.

K. Burke: Continental Margin between the Ivory Coast and Gabon.

P. Giresse: Sediments in the Gabon Delta.

G. Giermann: $x$ National and international programmes (East Atlantic Continental Margin).

K. C. Dunham: x Gravel, Sand, Metallic Placer and othe $\mathbf{r}$ Mineral Deposits on the EACM.

L. G. Murray et al: $x$ Diamonds on the EACM.

G. N. Baturin: $x$ The autigenic Phosphorite Formation as an Example of recent Phosphate Facies.

S. E. Calvert: Recent Sediments of the S. W. African Continental Shelf.

G. M. Bryan and E. S. W. Simpson: Seismic Refraction Measurements, Orange River to Capetown.

R. V. Dingle, I. Gerrard, R. I. Gentle, E. S. W. Simpson: The Continental Shelf between Capetown and Cape Agulhas.

C. Fothergill: $x$ Oil and Gas on the East Atlantic Continental Margin.

R. S. Dietz, J. C. Holden, W. Sproll: Continental Drift Evolution of the Atlantic Basin.

B. C. Heezen and H. D. Needham: The Continental Rise of North-West Africa.

$\mathbf{x}=$ Invited general lectures

$\mathrm{xx}=$ Invited regional review lectures

Geochemical Exploration Symposium, Toronto, Ontario, April 16 - 18, 1970.

An international geochemical exploration symposium will be held at the King Edward Hotel, Toronto, Ontario on April 16, 17, and 18, 1970, under the sponsorship of the Canadian Institute of Mining and Metallurgy and the Society of Economic Geologists. The program will 
include papers on all aspects of geochemical work as it affects exploration for minerals, petroleum, and natural gases. Special emphasis will be placed on new methods and on methods for discovering deeply buried deposits.

At the present time the organizing committee is interested in heargin from individuals who wish to submit papers or who may wish to take part in discussions.

Will you please inform your friends in the exploration business about this meeting and ask them to get in touch with -

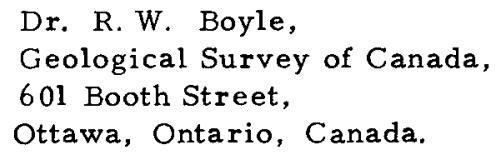

about papers, discussions, and other details of the meeting.

Further information on the meeting will be published later in the mining and geological press.

International Conference on the Utilization of Tidal Power, Halifax, Nova Scotia, May 24-29, 1970.

Under the auspices of the Atlantic Industrial Research Institute and the Nova Scotia Technical College, an international symposium on the various factors associated with the utilization of tidal power will be held May 24-29, 1970, at Nova Scotia Technical College in Halifax. The conference will be specifically addressed to the following topics: tidal containment, materials, problems, economics, power unit design, systems interconnection, and pollution control.

A nucleus of invited papers of a review nature will be presented together with submitted papers covering original research, and available as preprints if possible. All papers and discussion will be published as a book. Dr. T. J. Gray, professor of graduate studies, and Dr. O. K. Gashus, chairman of the department of electrical engineering will act as co-chairman of the meeting. For further information enquiries should be directed to Dr. Thomas J. Gray, Director, Atlantic Industrial Research Institute, c/o Nova Scotia Technical College, P. O. Box 1000, Halifax, Nova Scotia.

Joint Annual Meeting of the Geological Association of Canada and the Mineralogical Association of Canada, Winnipeg, Manitoba, August 30-September 2, 1970.

The Manitoba Mines Branch and the University of Manitoba will be co-hosts for the 1970 Joint Annual Meeting of the Geological and Mineralogical Associations of Canada, to be held at the Armes Lecture Theatre, University of Manitoba 19, Manitoba, from August 30 to September 2, 1970. The meeting will include the following:

The General Session

Papers are invited for presentation under the regular topical divisions:

I Economic Geology

II Mineralogy and Crystallography

III Geochemistry and Petrology

IV Geomorphology, Hydrogeology and Quaternary Geology

V Geophysics and Structural Geology

VI Stratigraphy, Paleontology and Sedimentology

VII Engineering Geology

Tentative titles of papers should be submitted not later than December 15, 1969 to the Program Chairman, Dr. D. T. Anderson, Department of Earth Sciences, University of Manitoba, Winnipeg 19, Manitoba. The deadline for final titles and abstracts will be March $15,1970$. 
Earth Science Symposium on Offshore Eastern Canada, Ottawa, Ontario, February 22-24, 1971.

An Earth Science Symposium on Offshore Eastern Canada will be held in Camsell Hall, 588 Booth Street, Department of Energy, Mines and Resources, Ottawa on February 22-24, 1971. Sponsors for the meeting are the Associate Committee on Geodosy and Geophysics: of the National Advisory Committee on Research in the Geological Sciences. The Chairman of the Program Committee is Dr. Peter Hood, Room 573, Geological Survey of Canada, Ottawa 4, Ontario, Canada (Telephone: 613-994-5652). The main objective of the Symposium is to summarize our present knowledge of the continental shelves and slopes of eastern Canada so that emphasis will be on results rather than techniques, although descriptions of new techniques will be encouraged. Areas to be discussed are the Bay of Fundy, Scotian Shelf, Gulf of St. Lawrence, Grand Banks, Flemish Cap, Labrador Sea, Ungava Bay, Baffin Bay and Greenland Shelf. The topics will include Surficial Geology, Geochemistry, Repetitive-Source Seismic, Bedrock Geology and Tectonics, Seismic Reflection \& Refraction, Gravity, Magnetics, Magnetotellurics, Crustal Seismic, Heat Flow, Continental Drift, and Offshore Drilling. Papers are invited for this 2-1/2 day symposium. Abstracts should be submitted before November 1 , 1970. A number of papers have already been offered mainly by government agencies and the universities, and there has been some response from industry. It is recognized that the symposium will be a greater success by widespread industry participation. It is therefore urged that individuals and representatives of exploration companies indicate to Dr. Hood their degree of interest.

24th International Geological Congress, Montreal, Quebec, Canada, August 1972.

Montreal will be the site for the 24th International Geological Congress in 1972 . At a recent meeting of the National Organization Committee in Montreal Dr. Robert Folinsbee, Edmonton, IGC Organizing Chairman, stated that Canadian geologists will prepare the best of all Congresses and show to the world that Canadian geology has a diversity of uncomparable scope. The National Committee is composed of more than 60 prominent geoscientists from across Canada in government, industry and universities. Dr. J. E. Armstrong, Vancouver, as Secretary-General for the Congress, will co-ordinate an extensive programme with both local and national scope.

The Congress will extend over a period of almost four weeks in late August and early September, 1972. Over 50 field trips, under the direction of Dr. M. E. Hriskevich, Calgary, which will allow delegates access to every part of Canada including the Arctic Islands, will familiarize geologists from around the world with the diversity and economic potential of. Canada's geological setting. Professor R. A. Blais, Chairman of the Montreal committee, is anticipating 6500 delegates. Ten days of scientific sessions with presentation of over 500 papers will be co-ordinated by Dr. Charles Smith, Ottawa. Particular emphasis will be placed on economic mineral resources, the continental shelves, the training of earth scientists, and the determinations of geological age across the continents.

The first International Geological Congress Newsletter is now available. Your request for a copy should be sent to C. G. Winder, Geology, University of Western Ontario, London, Canada. Individuals who wish to insure receipt of the First Circular for the International Geological Congress, Montreal, 1972, should send a request to Secretary General XXIV IGC, 601 Booth Street, Ottawa, Canada.

The first circular publicizing the 24th Congress will be mailed before the end of 1969. More than 50,000 copies will be distributed. The sources of addresses are 1) the list of 4000 plus Canadian geologists compiled for the Solid Earth Science Study group, 2) the mailing list for GEOTIMES being supplied ready for mailing by the American Geological Institute, 3) the membership lists of past Congresses and 4) lists provided by National Committees. The Executive Committee is particularly anxious to contact geologists in othe $\mathbf{r}$ parts of the world. You are requested to send - NOW - to Congress headquarters - Secretary General, 24 I. G. C., 601 Booth Street, Ottawa - the names of individuals and especially organizations - institutes, surveys, associations - who would wish to receive the notifications. 